\title{
Spatio-temporal analysis of sediment yield estimation using integrated RUSLE and GIS Technique: Case of Nashe Dam reservoir, Abay basin, Ethiopia.
}

\author{
Habtamu Tamiru $* 1$, Meseret Wagari ${ }^{2}$ \\ ${ }^{1}$ Department of Water Resources and Irrigation Engineering, Wollega University, P.O.B 395, \\ Ethiopia, email address: habtamutami@wollegauniversity.edu.et \\ ${ }^{2}$ Department of Natural Resources Management, Wollega University, P.O.B 395, Ethiopia, email \\ address: meseret123wag@gmail.com
}

\begin{abstract}
Sediment accumulation in a dam reservoir is a common happening environmental problem throughout the world. Topographic conditions, land use land cover change, the intensity of rainfall, and the soil characteristics are the major driving factors for sedimentation to occur. The effect of sedimentation in a dam reservoir is very visible in the watershed as a result of hilly topographic conditions, high rainfall intensity, thin land cover, and less soil infiltration capacity. In this paper, an integrated RUSLE and GIS technique was implemented to estimate a mean annual sediment yield based on spatial and temporal variations in Nashe dam reservoir situated in Fincha catchment, Abaya River basin, Ethiopia. Spatial and temporal estimation of mean annual sediment yield was estimated using the Revised Universal Soil Loss Equation (RUSLE) model and GIS. Historical 6year (2014-2019) rainfall for the temporal variations and other physical factors such as soil erodibility, slope and length steepness, management and land used land cover, and support practice for spatial variations were used as sediment driving factors. The mean annual sediment yield ranges from 0 to 2712.65 tha-1 year-1 was seen. Spatially, Very high, high, moderate, low, and very low sediment yield severity with total area coverage with $25 \%, 10 \%, 30 \%, 15 \%$, and $20 \%$ in $2017,2015,2019,2014$, and 2018 respectively. The information about the spatial and temporal variations of the severity of sediment yield in RUSLE model has a paramount role to control the entry of sediment into the dam reservoir in this watershed. The results of the RUSLE model can also be further considered along with the watershed for planning strategies for dam reservoirs in the catchment.
\end{abstract}

Keywords: GIS, RUSLE, Sediment Yield, Spatial Variation, Temporal Variation

\section{INTRODUCTION}

Sediments are get collected and formed after the disintegration of soil materials and transported water and wind[1]. Sediments formed by water erosion and accumulation of such sediments are very common in dam reservoirs[2]. Almost all rivers transport sediments and when the velocity of flowing water in the river bank is reduced due to the blockage structure such as weir and dam, and as the river enters into the reservoir, most of the sediment's particles settle beneath the reservoir[3],[4], and[5].

The initial point for sediment deposition in a dam reservoir is soil erosion in which the soil particles are detached and transported by agents like water and wind[6]. The quantity of sediment and direction of discharging increases with the velocity of runoff and transporting capacity of the overland flow in which a decrease in transport capacity enables sediment particles to settles in the reservoir[7]. Speedy soil erosion is a solemn concern globally, and it is very difficult to investigate the negative impacts of the problem on the economy and environment due to its extent, magnitude, annual rate of impacts, and its dynamic nature. Human activities[8] interferences such as 
infrastructure construction, traditional agricultural practices, urbanization, and mining can accelerate the rate of soil erosion which in turn increase the sedimentation rate[9]. The inflow of sediment and accumulation can negatively affect the capacity and function of reservoirs, and that is why the quantification of sediment rate or yield is important before sedimentation could disturb the useful functioning of the structure. If there is no sufficient storage capacity in the design, it is obvious the deposition can harm the regular functioning of the dam[10].

The process by which sedimentation can occur is quite intricate due to the interrelationship between the significant factors such as hydrological process, the variation of sediment particles, and the situation of reservoir operation mechanisms[11]. The ways of agricultural practices, the land use land cover, the severity of the soil to erosion, and the topographical conditions of the upstream areas may be a causative factor for the sediment to enter into the reservoir. Environmental protection is the central processing unit to control the sediment entrance into a reservoir, and once the sediment yield is estimated, the negative impacts of the sedimentation processes on the functioning of the reservoir are assessed. Fixing the annual sediment inflow, the efficiency of a reservoir in trapping sediment particles, and the ultimate deposition rate are should be done during the design period[1],[12].

The total capacity of the reservoir includes the storage volume required to tolerate the sediment deposition in addition to the normal design. Many pieces of research[13][14][10] were conducted in the estimation of the total mean annual sediment; however, space and timely accurate issues of the sedimentation were not reached. The estimation of a lumped sum average annual sediment yield cannot give sufficient information about spatial variation of the sedimentation severity and the exact time at which this problem will more likely happen[15][16]. The uncertainty in space and time is due to different factors such as natural factors (the intensity of rainfall, the slope of the upstream areas, the erodibility of the soil) and human-related factors such as mismanagement of water and land resources, land use land cover changes and misutilization of natural resources. The spatial and temporal variations consideration has a paramount role in the accuracy of sediment yield quantification for any time scale[6][11].

Plenty of researches and methods are available worldwide for assessment of sedimentation of a reservoir is related to soil erosion in water is used as agent. The significant factors such as rainfall intensity, erodibility of soil, the topographic conditions are commonly considered in the Universal Soil Loss Equation (USLE) for soil erosion assessment[17][18]. This research has got international attention and many scholars get involved and took the principles of soil erosion to the advanced levels in which other significant factors were added and the methods were later changed into Revised Universal Soil Loss Equation (RUSLE)[7].

The interesting side of the RUSLE in the soil loss estimation is that all significant factors are processed in ArcGIS by implementing the disintegration model (RUSLE) and the Spatio-temporal aspects are integrated to increase the accuracy in sediment yield estimation. The amount of sediment discharging into Nashe dam reservoir is dramatically increasing due to the natural and man-made factors from the upstream areas[19][20]. Nashe dam reservoir is located in Fincha catchment of Abay River, and due to the topographic conditions, poor farming practices, and high intensity of rainfall, the reservoir is vulnerable to sedimentation[3]. This paper aimed to present the estimation of annual mean sediment yield on the basis of spatial and temporal variations using an integrated RUSLE model and GIS. 


\section{MATERIALS AND METHODS}

\subsection{Description of study area}

This study area is conducted in Nashe dam reservoir which is located in Fincha catchment, Abay River basin, Ethiopia. Oromia regional state is the political-administrative boundary in which this dam reservoir is situated. It is bordered by Abay Chommen district in the southeast, by Jardega Jarte in the North West and Jima Ganati district in the southwest. It is located between $9^{\circ} 34^{\prime} 00^{\prime \prime}$ $\mathrm{N}$ and $37^{\circ} 06^{\prime} 00^{\prime \prime} \mathrm{E}$ and at an elevation of $2576 \mathrm{~m}$ above sea level. Particularly the study under consideration was delineated fixing the outlet at the dam site. In this study area (Fig. 1), the delineated watershed is geographically found between $3700.06^{\prime} 00^{\prime \prime} \mathrm{E}$ to $37033^{\prime} 18^{\prime \prime}$ E longitude and $09021^{\prime} 11^{\prime \prime} \mathrm{N}$ to $10001^{\prime} 00^{\prime \prime} \mathrm{N}$ latitude. The delineated watershed (Fig.1) and reservoir in the watershed have $335.94 \mathrm{~km} 2$ total area, and $17.09 \mathrm{~km}^{2}$ respectively and the reservoir area cover about $5.09 \%$ of the total area of the watershed.

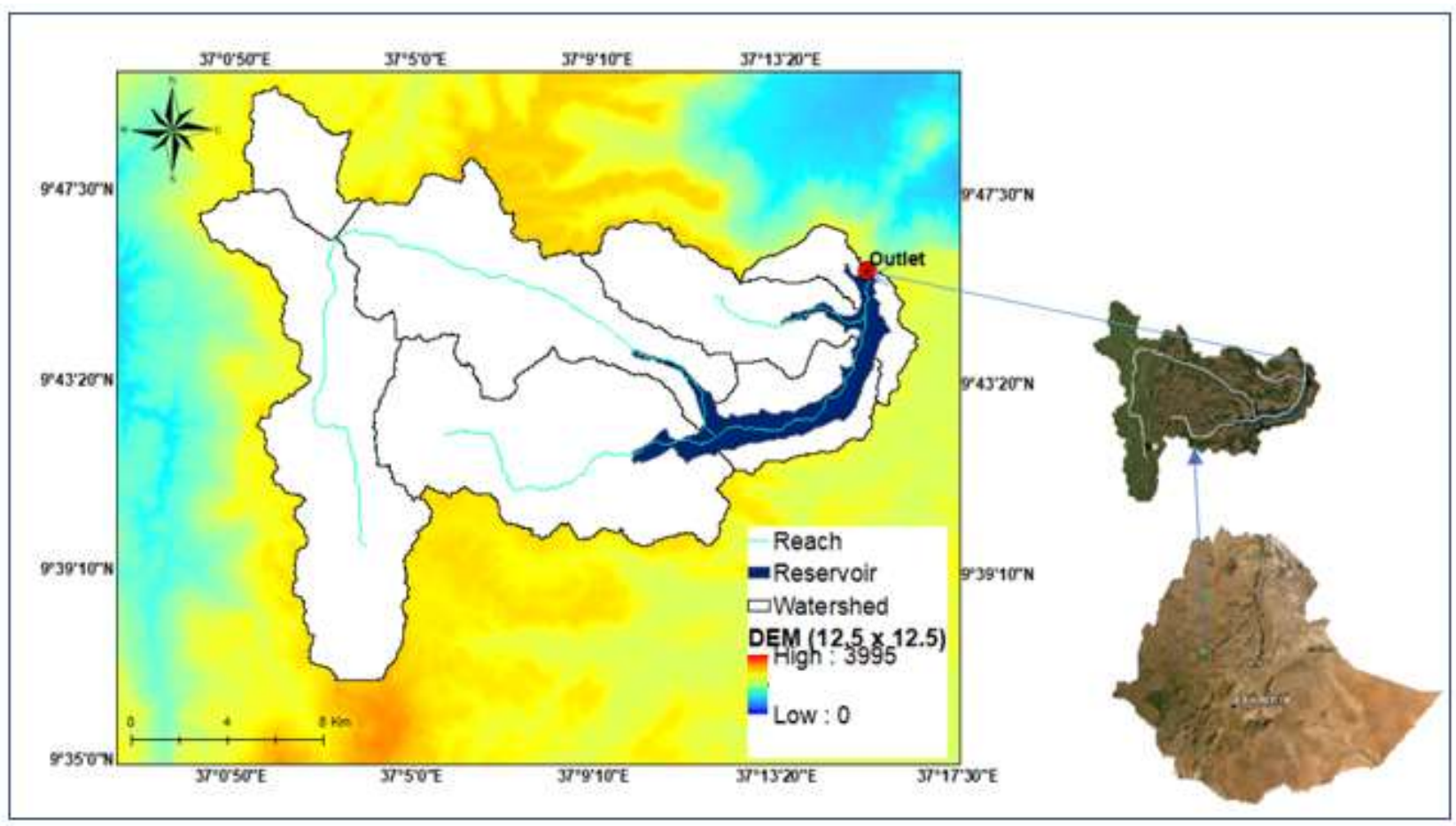

Figure 1: watershed, river networks and reservoir in the study area

\subsection{Methodology}

This paper estimation of mean annual sediment yield on the basis of spatial and temporal variations using an integrated Revised Universal Soil Loss Equation (RUSLE) model and GIS[9][18][21][22][23][16]. The disintegration and the transporting mechanisms behind sediment particles are due to the interaction between soil erosion driving factors[24]. The physical interactions between these significant factors can initiate the formation of soil erosion whereas water as an agent transport the eroded sediment particles from the point of detachment to the reservoir area. RUSLE as disintegration model and GIS for the generation of significant factors were integrated to estimate the spatial variation of sediment yield in the watershed and severity map on the basis of time variation of the sediment accumulation. Sediment yield estimation using RUSLE was applied in most of the catchments in Abay basin, but Fincha which is one of the 
catchments in the basin and where the severity of the sediment yield in the reservoir is very visible was not reached yet previously and was reached by this study. To achieve the objective of this study, the major soil erosion driving parameters such as erosivity factor, erodibility factor, Length and steepness factor, management practice factor, and cover management factor was used and geodatabase for each factor was prepared in ArcGIS. Once these factors were generated in ArcGIS, the mean annual sediment yield was estimated using the RUSLE model developed in the spatial analyst tool. A model builder was developed and a map algebra algorithm was used to estimate the mean annual sediment yield (Eq.1).

\subsection{RUSLE model for sediment yield estimation}

In this study, RUSLE was used to generate the spatially varied soil erosion severity map by combining five factors. The thematic maps of the raw input parameters of the significant factors (R-factor, P-factor, K-factor, LS-factor, and C-factor) were prepared with $12.5 \times 12.5 \mathrm{~m}$ spatial resolution. A map algebra algorithm in spatial tool analyst and a model builder (Fig.4) developed in ArcGIS were implemented to combine the significant factors using the RUSLE equation as shown below. The general flowchart showing the detailed procedures and data needed is summarized in (Fig. 3).

$$
A=R * K * L S * C * P
$$

Where A The total annual soil loss ( $\mathrm{t} / \mathrm{ha}$ per year), $\mathrm{t}$ is the thickness of lost soil

$\mathrm{R} \quad$ Rainfall erosivity factor (MJmm ha- $\mathrm{h}^{-1}$ year $^{-1}$ )

$\mathrm{K} \quad$ Soil erodibility factor $\left(\mathrm{t} \mathrm{haMJ} \mathrm{mm}^{-1}\right)$

LS Slope length and steepness factor (dimensionless)

C Over and management factor (dimensionless)

P Support practice factor (dimensionless)

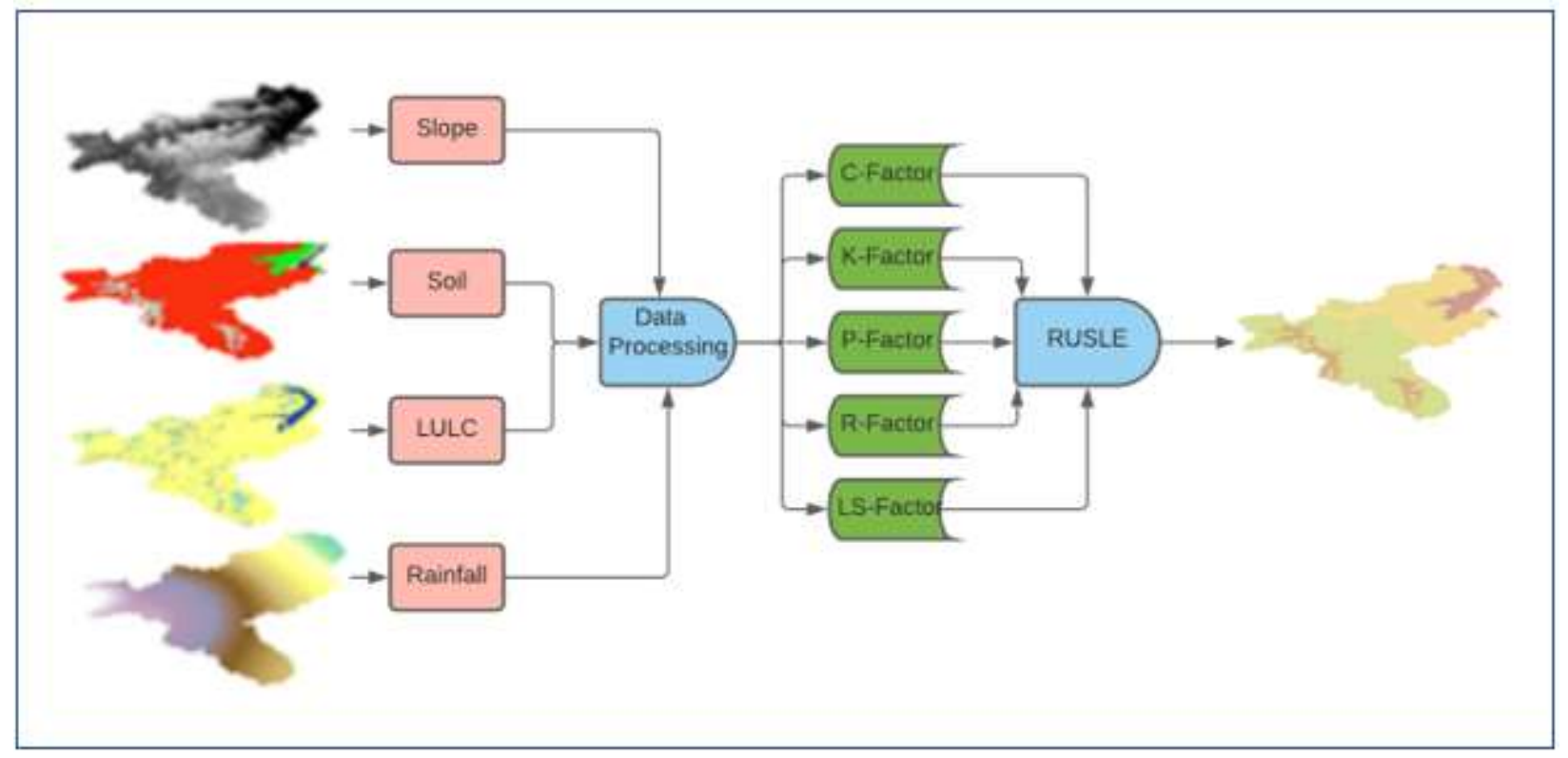

Figure 2: Sediment yield driving factors, and estimation conceptual frame work 


\subsection{Rainfall erosivity factor $(R)$}

The rainfall erosivity factor $(\mathrm{R})$ describes the relationship between the rainfall intensity and the soil responses to it[17][8]. In this catchment, the spatial variability of the intensity of the rainfall varies from $1353.65 \mathrm{~mm}$ to $2030.93 \mathrm{~mm}$. There is a positive relationship between the intensity of the precipitation and the soil characteristics in such a way that if the intensity is very high, there is the probability of severe soil erosion[25]. Six years of historical mean annual precipitation of 11 stations (Table 1 and Fig.2) contributing to the catchment were considered in this study to generate information about erosivity in the area. An aerial raster geodatabase of rainfall was generated from the historical point rainfall data using Inverse Distance Weight (IDW) interpolation technique[26] with $12.5 \times 12.5 \mathrm{~m}$ spatial resolution using the regression equation developed by (Eq.2)

$$
R=1.24 * P^{1.36}
$$

Where $\mathrm{R} \quad$ Rainfall erosivity factor $\left(\mathrm{MJmm} \mathrm{ha}^{-1} \mathrm{~h}^{-1}\right.$ year $\left.{ }^{-1}\right)$

$\mathrm{P} \quad$ Annual mean precipitation $(\mathrm{mm})$

Table 1: Rainfall stations and mean annual rainfall $(\mathrm{mm})$

\begin{tabular}{lccccc}
\hline No. & Station Name & Long & Lat & Elevation $(\mathbf{m})$ & Precipitation $(\mathbf{m m})$ \\
\hline 1 & Alibo & 37.0795 & 9.8904 & 2405.53 & 1754.2 \\
2 & Kewo & 37.5543 & 9.8271 & 2362.15 & 1353.65 \\
3 & Jardega & 37.0143 & 9.8065 & 2402.98 & 2030.93 \\
4 & Sombo & 37.0326 & 9.7424 & 2385.78 & 1988.75 \\
5 & Dedu & 37.5357 & 9.6889 & 2270.19 & 1491.6 \\
6 & Achane & 37.3216 & 9.6547 & 2398.33 & 1645.81 \\
7 & Shambu & 37.0943 & 9.5707 & 2556.4 & 1827.07 \\
8 & Fincha-a & 37.362 & 9.5659 & 2226.33 & 1528.11 \\
9 & Kombolcha & 37.4781 & 9.5097 & 2390.25 & 1621.3 \\
10 & Bila & 37.0279 & 9.2925 & 2114.34 & 1728.16 \\
11 & Goben & 37.311 & 9.1741 & 2610.34 & 1906.2 \\
\hline
\end{tabular}

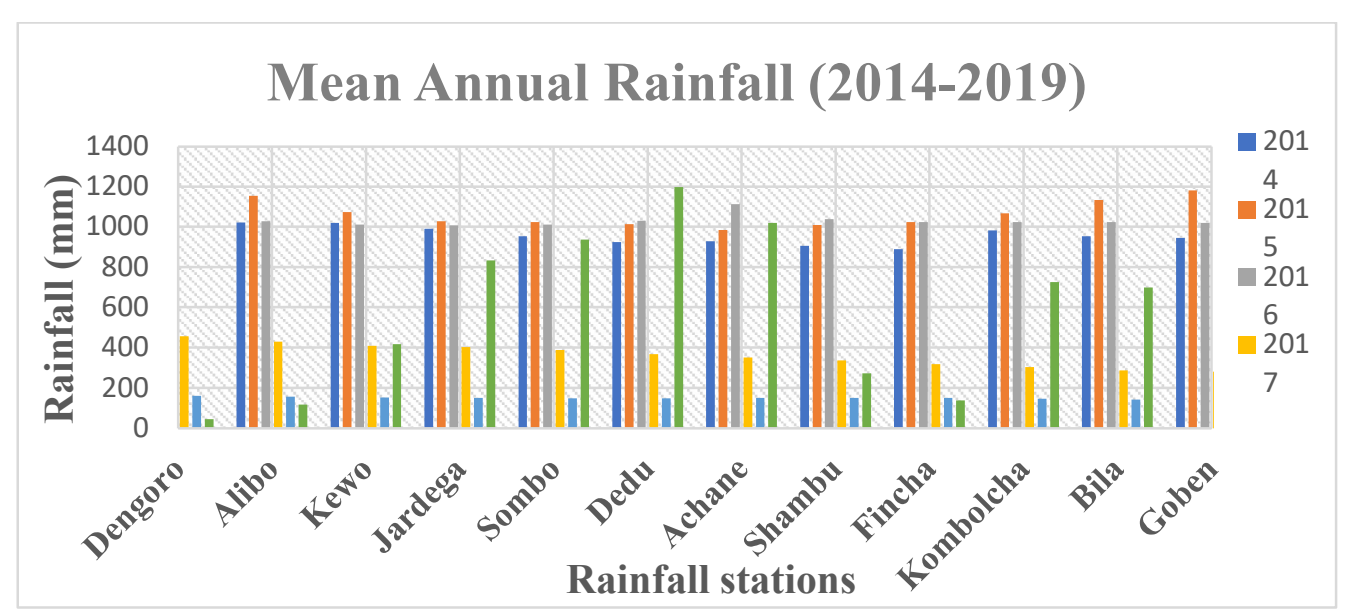

Figure 3: Rainfall stations and mean annual rainfall (mm) from 2014-2019

\subsubsection{Soil Erodibility factor $(K)$}

The properties of soil and the degree of erodibility are interconnected parameters. When the drop of rainfall hits the soil particles, there is a high probability of disintegration in soil particles when the soil hitting external force exceeds the cohesion forces between soil particles[27]. The ability of soil particles in persisting against rainfall is different in different soil types and this property is 
expressed in terms of erodibility factor[28]. In this catchment there are more than 10 soil types are available and reclassified into 6 dominant types (Fig.8) and k-values were assigned.

\subsubsection{Topographic Factor (LS)}

The severity of the spatial variability of soil erosion highly relies on the topographic conditions of an area. The steepness/flatness of an agricultural land governs the degree of the erodibility of soil particles. The speed of the water flowing over soil and the slope of the topography are dependent parameters[27]. The length of the slope and slope steepness of the area in the study area was generated using Digital Elevation Model (DEM) of $12.5 \times 12.5 \mathrm{~m}$ spatial resolution and LS-factor was generated in ArcGIS version 10.4. Flow accumulation and slope (\%) are commonly used input parameters with a fixed cell size with regression equation[8] (Eq.3).

$$
L S=\left\{\text { Flow accumalation } *\left(\frac{\text { Cell size }}{23.13}\right)\right\}^{0.4} *\left\{\frac{\sin (\text { slope }(\%) * 0.01745)}{0.09}\right\}^{1.3} * 1.6 \ldots \ldots \ldots \text { (3) }
$$

Where LS Slope length and steepness factor (dimensionless)

\subsubsection{Cover and Management factor (C)}

The types of cover and land use in agricultural land are highly interrelated factors. Raw input DEM was corrected by applying fill and flow direction in ArcGIS using spatial tool analyst. Slope (\%) and flow accumulation were generated for the study area and reclassified based on the c-values in spatial tool analyst. The types of land use land cover (LULC) in the study area (Fig.5) and the corresponding c-values (Table 3) were assigned. In the same fashion, the values for support practice factor $(\mathrm{P})$ were generated from the land use land cover map.

\section{RESULT AND DISCUSSIONS}

\subsection{Sediment yield estimation using RUSLE model}

The estimation of mean annual sediment yield based on spatial and temporal variations in the watershed was presented (Fig.9-11). In the delineated watershed, there are seven sub-watersheds and were labeled by default as W1, W2, W3, W4. W5, W6, and W7. The spatial issues of the sediment estimation done in this paper were summarized with the generated severity map (Fig.8). The timely accurate estimation of the mean annual sediment yield based on the mean annual rainfall of 6-years in the watershed was identified and mapped (Fig.10). The estimated mean annual sediment yield is generally ranging from 0 to $2712.652712 .65 \mathrm{t}$ ha -1 year- 1 . The thickness of sediment under deposition is dramatically increasing and there is evidence that the mean annual of $2712.65 \mathrm{t}$ ha -1 year-1 was obtained in 2017 . 


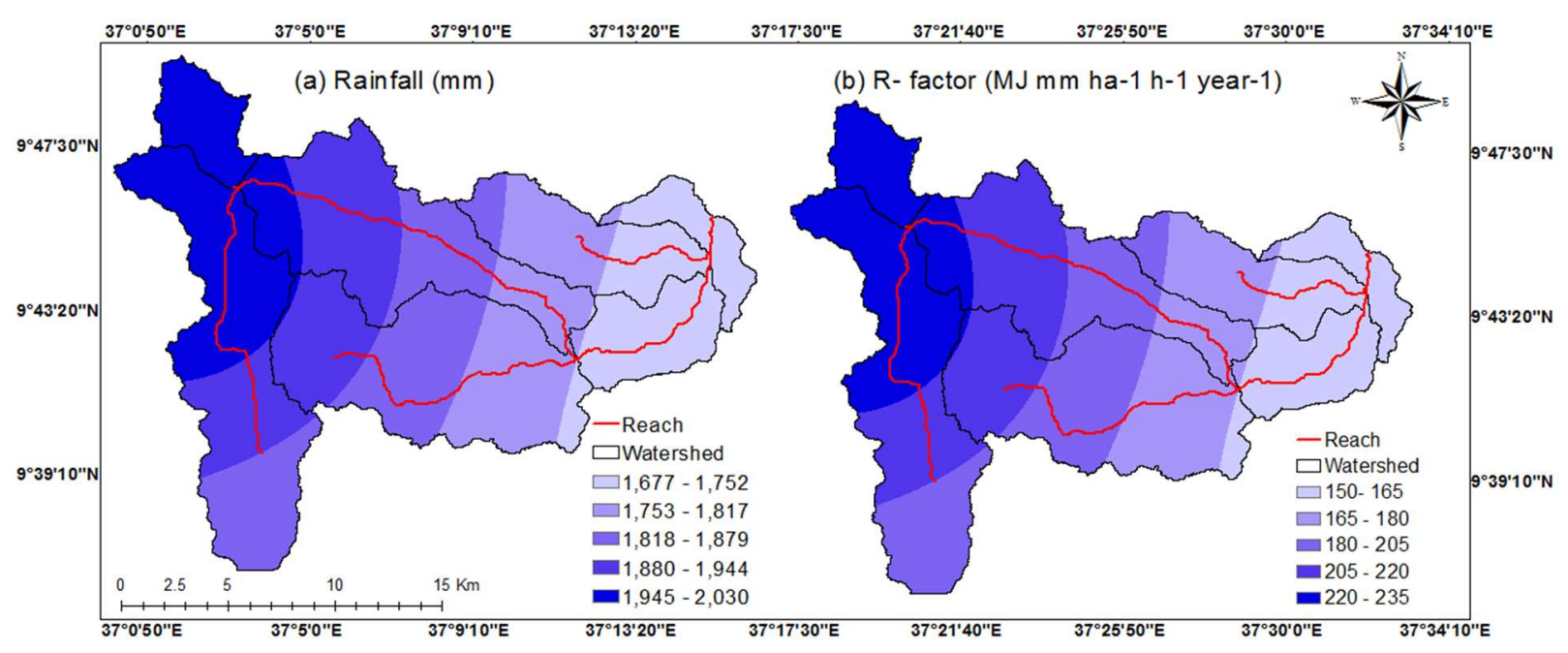

Figure 4: Rainfall erosivity factor (R-factor) values in the watershed

The temporal severity variation map based on qualitative classifications as very high, high, moderate, low, and very low were identified and this was linked with the spatial variations (Fig.8 \& Fig.9). The soil erosion severity map generated for each year revealed that $25 \%, 10 \%, 30 \%$, $15 \%$, and $20 \%$ were identified as very high, high, moderate, low, and very low, and the impacts were very visible in 2017, 2015, 2019, 2014 and 2018 respectively.

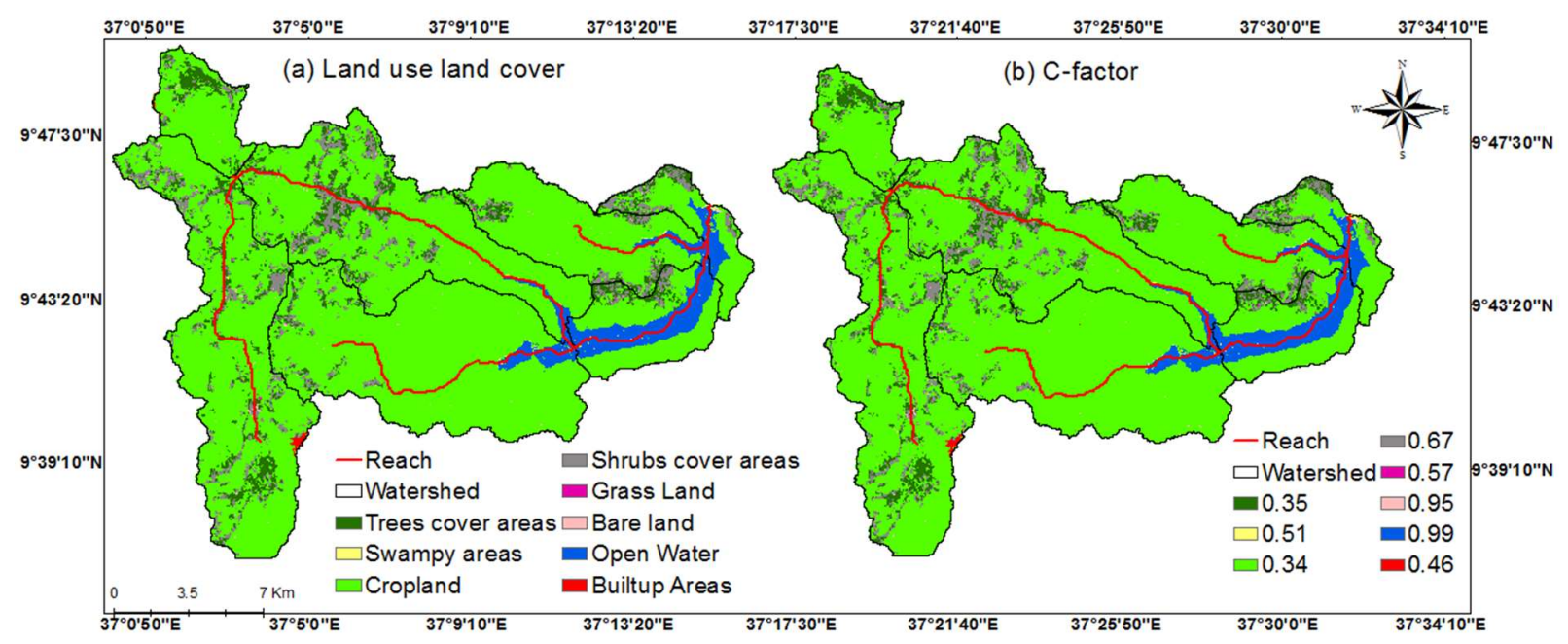

Figure 5: Major land use land cover (LULC) types and corresponding C-values

This is the novelty of this paper in which both the spatial and temporal variations are linked to getting a better understanding of mean annual sediment yield (Fig.9). As visualized in the severity map generated using the RUSLE model (Fig.8), the reservoir area which covers $5.09 \%$ of the total area is highly vulnerable to sedimentation and this effect is very visible in sub-watershed labeled as W1. The sub-watersheds such W2, W3, and W4 are contributing relatively high to moderate for the reservoir whereas sub-watershed W1 is the most contributing when compared to the others. In terms of the significant factors; rainfall erosivity (R-factor), cover and management(C-factor), and support and conservation practice (P-factor) factors revealed high significant contribution while the other factors are relatively low significant contribution for the initiation of sediment deposition, 
and the values of the corresponding factors were shown in (Fig.4-5). The spatial variability of mean annual rainfall shown in (Fig.10) showed that the majority of crop and agricultural lands surrounding the reservoir sites are very sensitive to sediment and this fact is observed in the severity map (Fig.9). The rate of mean annual sediment yield seen in the reservoir is higher than the total annual soil formation rate ranges from 2 to $22 \mathrm{t} / \mathrm{ha}$ per year for the different land uses units of Ethiopia [8] and special attention should be given to minimize the rate of sediment yield entry into the reservoir by implementing soil formation strategies or soil and resources management strategies. Support and conservation practices factor (P-factors) values were assigned based on the soil types in the study area. The soil map was reclassified into six dominant soil types and the corresponding p-factor values were given (Fig. 6).

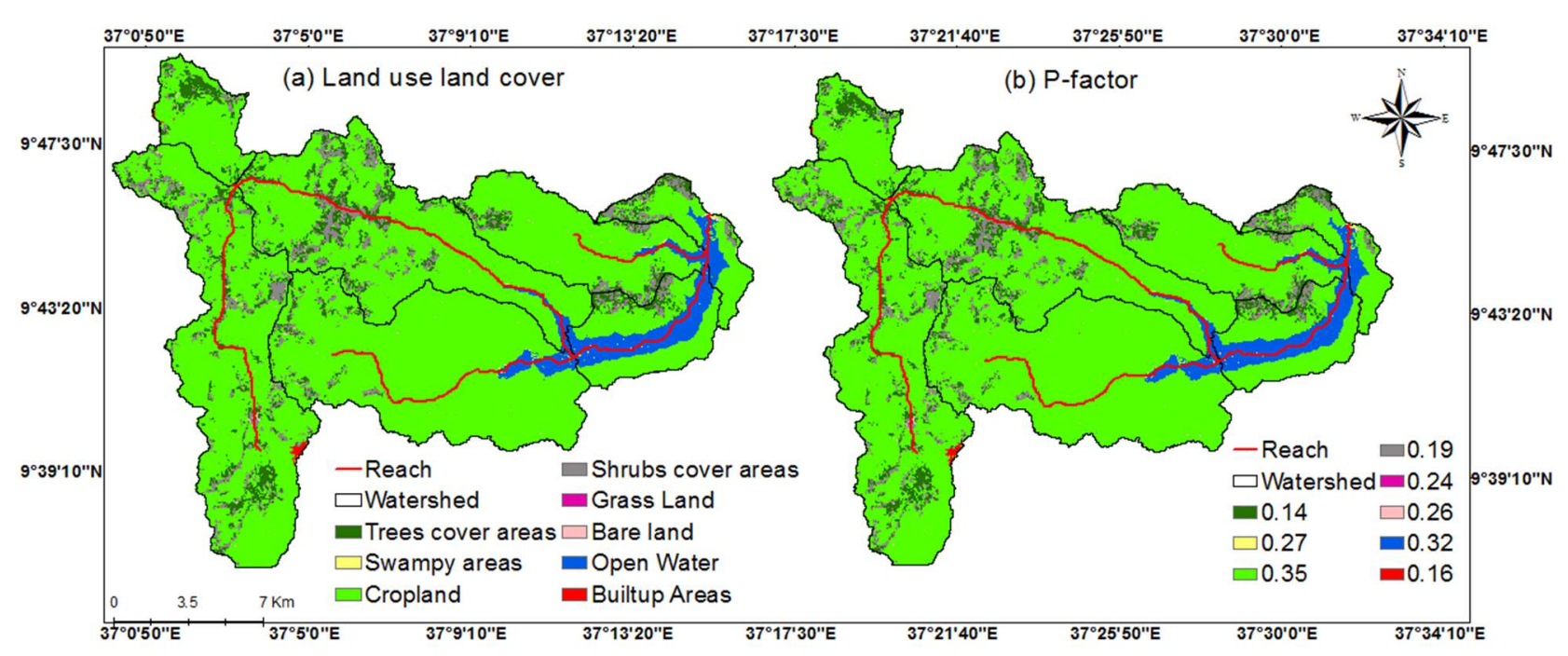

Figure 6: Support and practice factor (P-factor) values in the watershed

The low-land agricultural areas in this watershed are less vulnerable to soil erosion and relatively less sedimentation problem is visible[16] due to the low velocity of runoff water. The traditional way of agricultural systems and soil conservation practices is very weak in the lower part of the study area, therefore, the support and conservation practices factor (p-factor) reveals that the croplands and bare land are very exposed and sensitive to erosion due to the incoming runoff water from the highland areas[16]; Kayet et al., 2018).

There is another evidence that slope length and steepness (LS) is also another factor that describes the sensitivity of soil disintegration of soil particles and causing detachment of soil particles, which in turn lead to sedimentation. In this watershed, the slope ranges from 0 to $59.37 \%$ (Fig.), and due to the steepness of the slope, the soil loss is very visible especially for the slope values of more than $11 \%[6]$. The ranges of slope in degree and the corresponding LS-factor values were generated (Fig.7) according to the studies conducted by (Dinka, 2020;Thapa, 2020). 


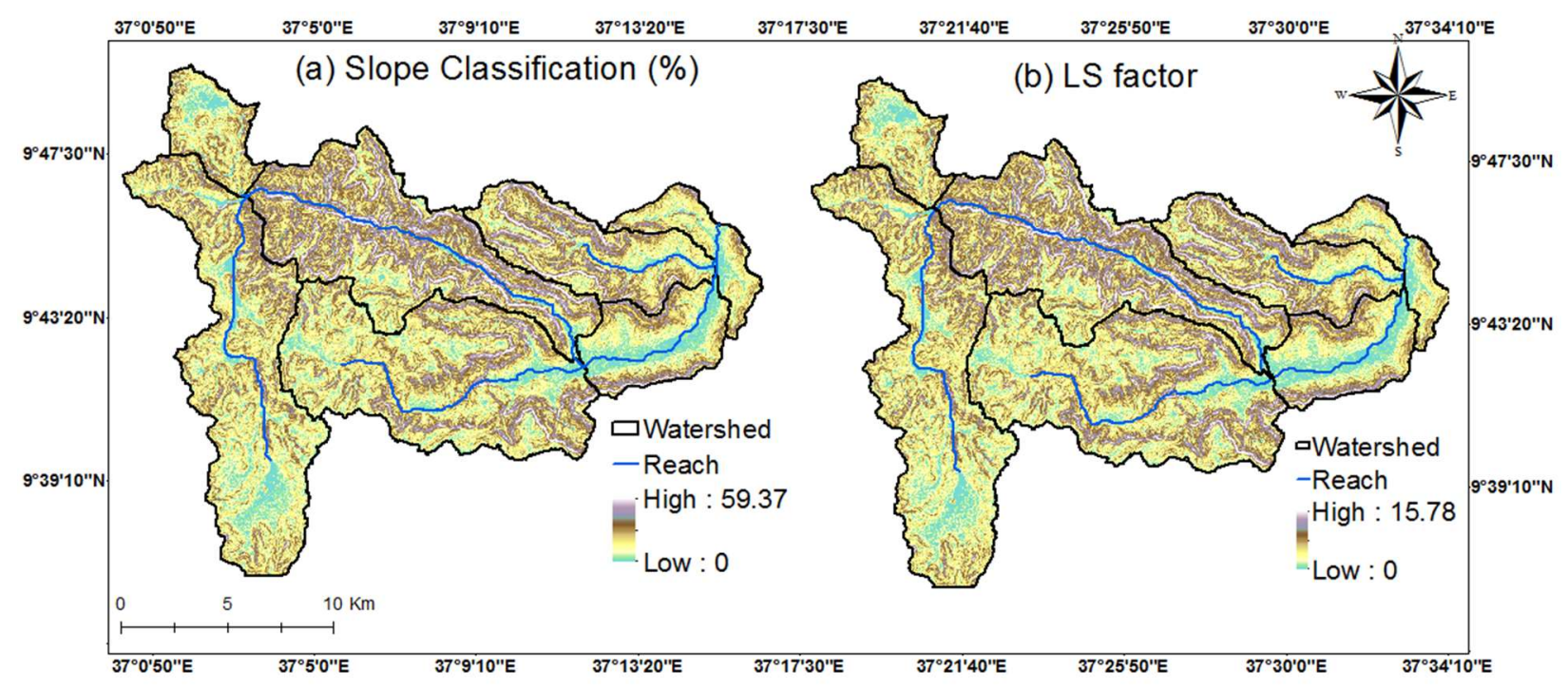

Figure 7: Slope classificxations, and length and steepness (LS) factor values

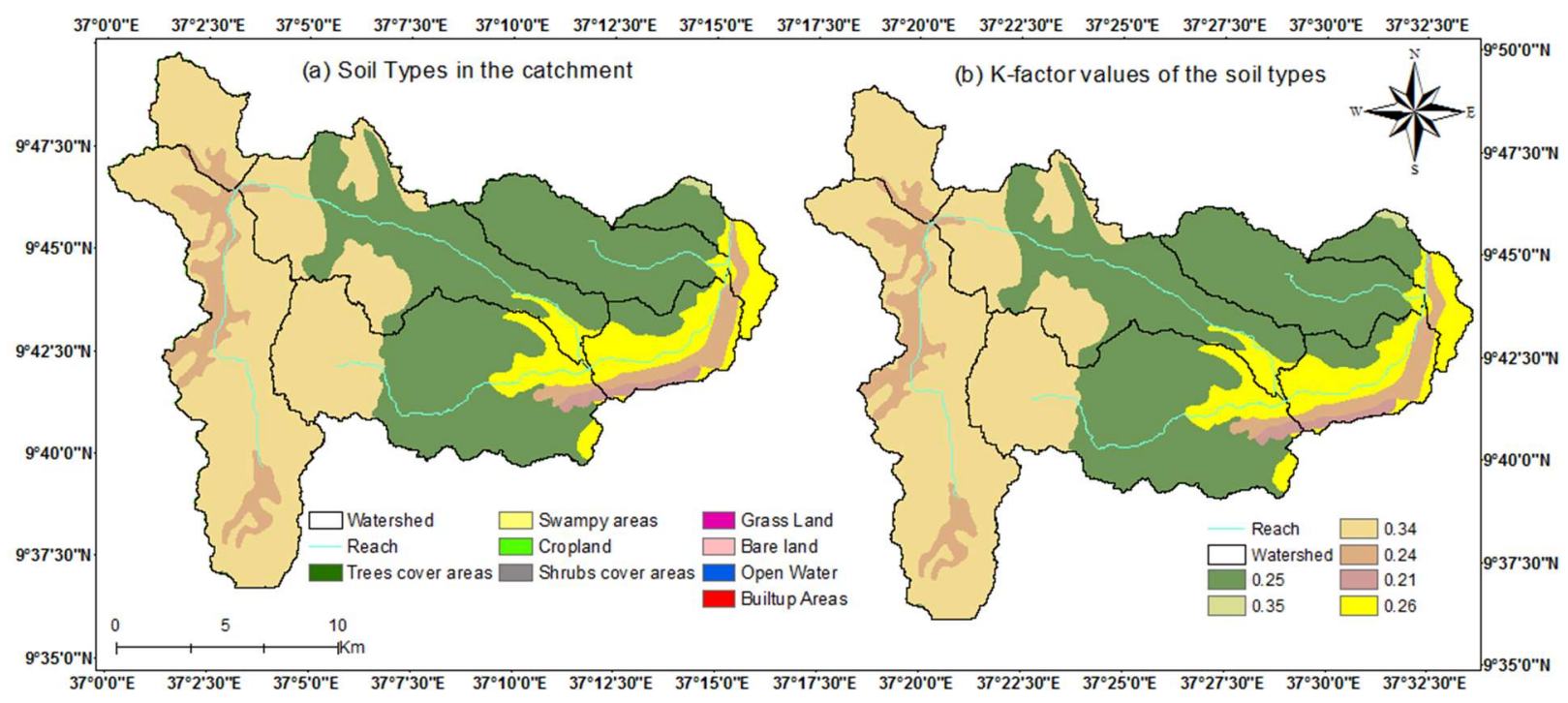

Figure 8: The soil classifications, and the corresponding K-values in the watershed

A model builder for the RUSLE model was developed and raster map algebra was applied in ArcGIS version 10.4 to quantify the total annual soil loss. The results of the RUSLE model can also be further considered along with the watershed for practical mean annual sediment yield estimation that can help for protection practices. 


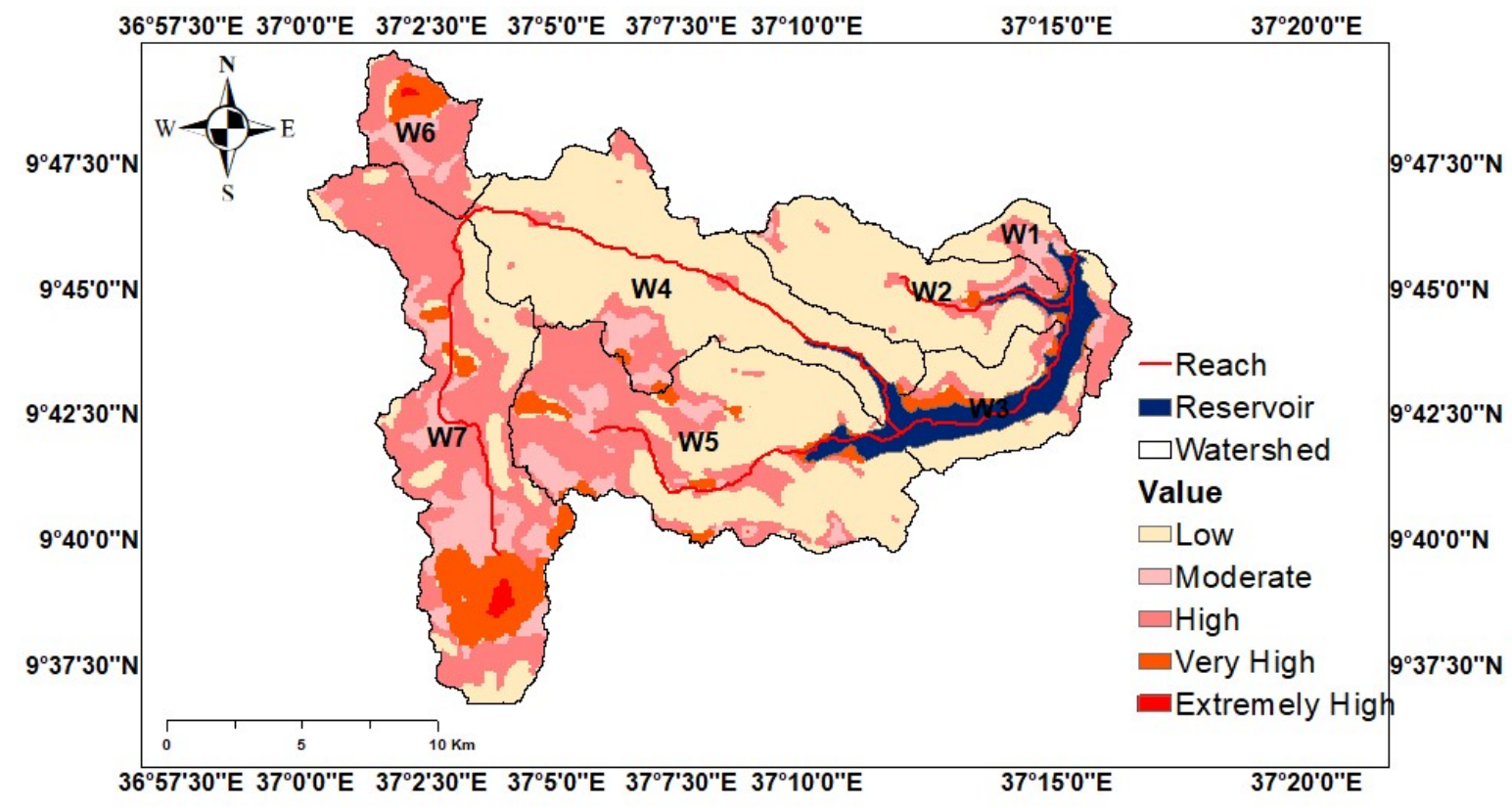

Figure 9: Spatial variation of severity map for sediment yield in the watershed

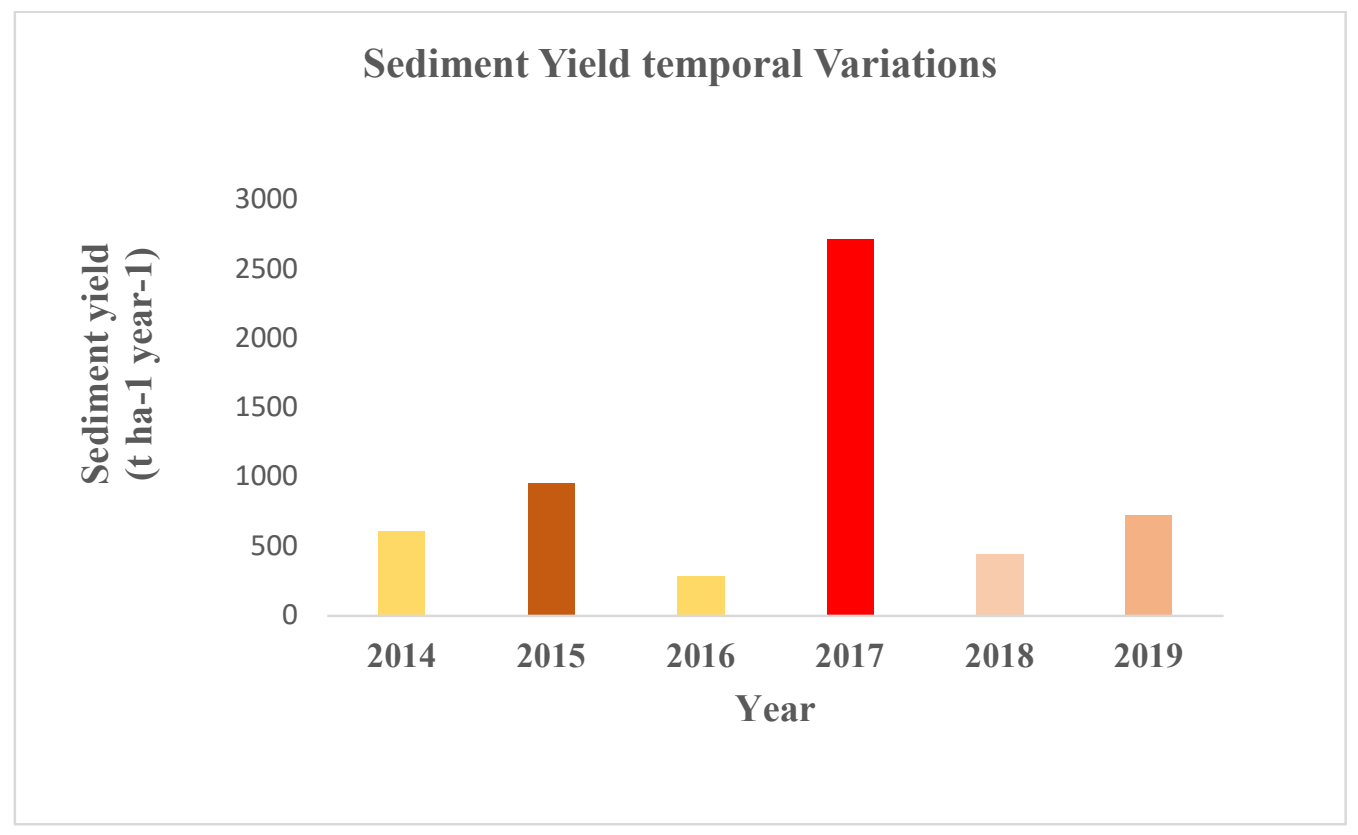

Figure 10: Mean annual sediment yield temporal variations 


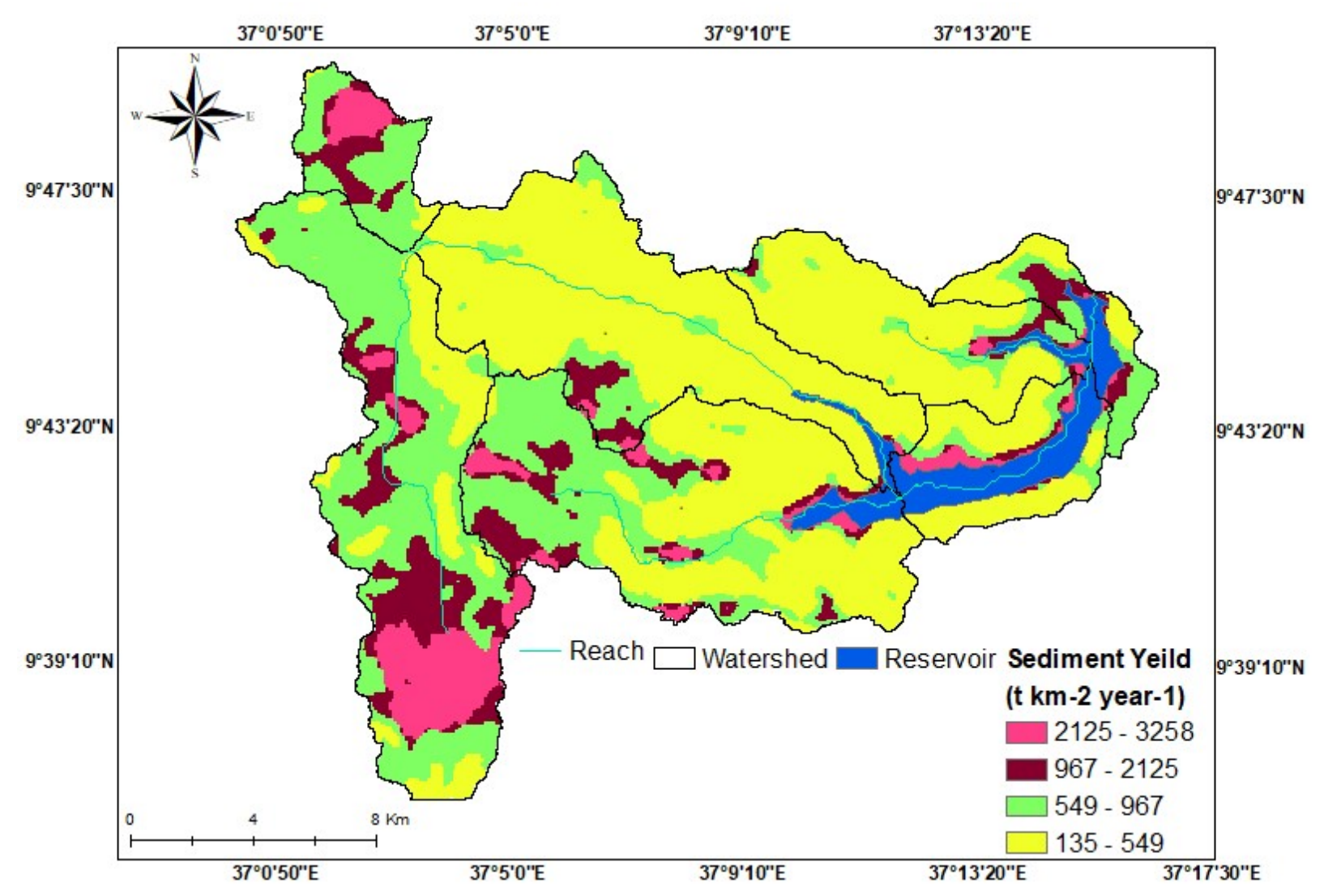

Figure 11: Mean annual sediment yield spatial variation in the watershed

\section{CONCLUSION}

The estimation of mean annual sediment yield using an integrated RUSLE model and GIS is successfully presented based on spatial and temporal variations in Nashe dam reservoir of Fincha catchment situated in Abay basin, Ethiopia. It was found that there is a serious problem of sediment deposition and it dramatically increasing sediment yield in the reservoir ranging from 0 to 2712.65 t ha-1 year-1. Field survey and investigation obtained from the reservoir site revealed that there is a high expansion of the lake and this is most probably due to massive sediment particles entry into the reservoir. The spatial and temporal variations linked to the sediment yield estimated in this watershed present a good understanding of the application of the soil disintegration model (RUSLE) and GIS. The yield and severity of the sediment deposition in the reservoir vary with space and time that for the year having the highest mean annual rainfall value, the serous sediment deposition was attained. From this study, it was found that the sub-watersheds labeled as W1, W2, and W3 are discharging very high, high, and moderate sediment particles respectively and a soil conservation strategy should be implemented to control the sediment discharge in the watershed. Additionally, capacity-building training should be given for the farmers and soil conservation experts to minimize the man-made sediment driving factors such as deforestation and traditional way of farming practices. The information about the spatial and temporal variations of the severity of sediment yield in the RUSLE model has a paramount role to control the entry of sediment into the dam reservoir in this watershed. The results of the RUSLE model can also be further considered along with the watershed for planning strategies for dam reservoirs in the catchment. 


\section{REFERENCES}

[1] J. Eisenberg and F. A. Muvundja, "Quantification of Erosion in Selected Catchment Areas of the Ruzizi River (DRC) Using the (R)USLE Model," Land, vol. 9, no. 4, 2020, doi: 10.3390/LAND9040125. [2] M. Shiferaw and R. Abebe, "A spatial analysis and modeling study of sedimentation impacts on dams found in south Gondar zone, Ethiopia," Model. Earth Syst. Environ., no. Sichingabula 1997, 2020, doi: 10.1007/s40808-020-01003-5.

[3] F. Karamage et al., "Modeling rainfall-runoffresponse to land use and land cover change in Rwanda (1990-2016),"Water (Switzerland), vol. 9, no. 2, 2017, doi: 10.3390/w9020147.

[4] T. G. Andualem, Y. G. Hagos, A. Kefale, and B. Zelalem, "Soil erosion-prone area identification using multi-criteria decision analysis in Ethiopian highlands," Model. Earth Syst. Environ., vol. 6, no. 3, pp. 1407-1418, 2020, doi: 10.1007/s40808-020-00757-2.

[5] G. M. Kondolf et al., "Sustainable sediment management in reservoirs and regulated rivers: Experiences from five continents," Earth's Futur., vol. 2, no. 5, pp. 256-280, 2014, doi: 10.1002/2013ef000184.

[6] A. H. A. Ghani, T. Lihan, S. A. Rahim, M. A. Musthapha, W. M. R. Idris, and Z. A. Rahman, "Prediction of sedimentation using integration of RS, RUSLE model and GIS in Cameron Highlands, Pahang, Malaysia," AIP Conf. Proc., vol. 1571, no. December 2013, pp. 543-548, 2013, doi: $10.1063 / 1.4858711$.

[7] A. Maqsoom et al., "Geospatial assessment of soil erosion intensity and sediment yield using the Revised Universal Soil Loss Equation (RUSLE) model," ISPRS Int. J. Geo-Information, vol. 9, no. 6, 2020, doi: 10.3390/ijgi9060356.

[8] T. S. Abdulkadir et al., "Quantitative analysis of soil erosion causative factors for susceptibility assessment in a complex watershed," Cogent Eng., vol. 6, no. 1, 2019, doi:

10.1080/23311916.2019.1594506.

[9] D. Chalise, L. Kumar, V. Spalevic, and G. Skataric, "Estimation of sediment yield and maximum outflow using the IntErO model in the Sarada River Basin of Nepal," Water (Switzerland), vol. 11, no. 5, 2019, doi: 10.3390/w11050952.

[10] I. Ahmad, M. A. Dar, and T. G. Andualem, “Assessment of soil loss rate-Lake Tana basin, Ethiopia," Arab. J. Geosci., vol. 13, no. 1, 2020, doi: 10.1007/s12517-019-5013-9.

[11] C. Massmann, "Identification of factors influencing hydrologic model performance using a topdown approach in a large number of U.S. catchments," Hydrol. Process., vol. 34, no. 1, pp. 4-20, 2020, doi: 10.1002/hyp.13566.

[12] Y. Hategekimana, M. Allam, Q. Meng, Y. Nie, and E. Mohamed, "Quantification of soil losses along the coastal protected areas in Kenya," Land, vol. 9, no. 5, pp. 1-16, 2020, doi:

10.3390/LAND9050137.

[13] M. Getachew, D. Yewhalaw, K. Tafess, Y. Getachew, and A. Zeynudin, “Anaemia and associated risk factors among pregnant women in Gilgel Gibe dam area , Southwest Ethiopia," pp. 1-8, 2012.

[14] T. G. Andualem, G. Belay, and A. Guadie, "Land Use Change Detection Using Remote Sensing Technology," J. Earth Sci. Clim. Change, vol. 9, no. 10, 2018, doi: 10.4172/2157-7617.1000496.

[15] G. Singh and R. K. Panda, "Grid-cell based assessment of soil erosion potential for identification of critical erosion prone areas using USLE, GIS and remote sensing: A case study in the Kapgari watershed, India," Int. Soil Water Conserv. Res., vol. 5, no. 3, pp. 202-211, 2017, doi: 10.1016/j.iswcr.2017.05.006.

[16] R. Bhattarai and D. Dutta, "A comparative analysis of sediment yield simulation by empirical and process-oriented models in Thailand," Hydrol. Sci. J., vol. 53, no. 6, pp. 1253-1269, 2008, doi: 10.1623/hysj.53.6.1253.

[17] V. Prasannakumar, H. Vijith, S. Abinod, and N. Geetha, "Estimation of soil erosion risk within a small mountainous sub-watershed in Kerala, India, using Revised Universal Soil Loss Equation (RUSLE) 
and geo-information technology," Geosci. Front., vol. 3, no. 2, pp. 209-215, 2012, doi: 10.1016/j.gsf.2011.11.003.

[18] R. Yan, X. Zhang, S. Yan, and H. Chen, "Estimating soil erosion response to land use/cover change in a catchment of the Loess Plateau, China," Int. Soil Water Conserv. Res., vol. 6, no. 1, pp. 1322, 2018, doi: 10.1016/j.iswcr.2017.12.002.

[19] M. O. Dinka, "Quantification of soil erosion and sediment yield for ungauged catchment using the RUSLE model: Case study for Lake Basaka catchment in Ethiopia," Lakes Reserv. Res. Manag., vol. 25, no. 2, pp. 183-195, 2020, doi: 10.1111/lre.12312.

[20] G. G. Demeke and T. G. Andualem, "Application of Remote Sensing for Evaluation of Land Use Change Responses on Hydrology of Muga Watershed, Abbay River Basin, Ethiopia," J. Earth Sci. Clim. Change, vol. 9, no. 10, 2018, doi: 10.4172/2157-7617.1000493.

[21] D. Pimentel, "Soil erosion: A food and environmental threat," Environ. Dev. Sustain., vol. 8, no. 1, pp. 119-137, 2006, doi: 10.1007/s10668-005-1262-8.

[22] C. Fernandez, J. Q. Wu, D. K. McCool, and C. O. Stöckle, "Estimating water erosion and sediment yield with GIS, RUSLE, and SEDD," J. Soil Water Conserv., vol. 58, no. 3, pp. 128-136, 2003. [23] B. Iticha and C. Takele, "Soil-landscape variability: mapping and building detail information for soil management," Soil Use Manag., vol. 34, no. 1, pp. 111-123, 2018, doi: 10.1111/sum.12404.

[24] Ф. В. Тузиков, Ю. И. Рагино, Н. Л. Тузикова, М. В. Иванова, Р. В. Талимов, and Ю. П. Никитин, Ф.В. Тузиков2, Ю.И. Рагино1, Нл. Тузикова2, М.В. Иванова1, Р.В. Талимов2, Ю.П. Никитин1, vol. 41, no. 2. 2017.

[25] A. Y. Yesuph and A. B. Dagnew, "Soil erosion mapping and severity analysis based on RUSLE model and local perception in the Beshillo Catchment of the Blue Nile Basin, Ethiopia," Environ. Syst. Res., vol. 8, no. 1, pp. 1-21, 2019, doi: 10.1186/s40068-019-0145-1.

[26] T. A. Dessalegn, M. A. Moges, D. C. Dagnew, and A. Gashaw, "Applicability of Galway River Flow Forecasting and Modeling System (GFFMS) for Lake Tana Basin, Ethiopia,” J. Water Resour. Prot., vol. 09, no. 12, pp. 1319-1334, 2017, doi: 10.4236/jwarp.2017.912084.

[27] N. Kayet, K. Pathak, A. Chakrabarty, and S. Sahoo, "Evaluation of soil loss estimation using the RUSLE model and SCS-CN method in hillslope mining areas," Int. Soil Water Conserv. Res., vol. 6, no. 1, pp. 31-42, 2018, doi: 10.1016/j.iswcr.2017.11.002.

[28] B. Ayenew, A. M. Taddesse, K. Kibret, and A. Melese, "Chemical forms of phosphorous and physicochemical properties of acid soils of Cheha and Dinsho districts, southern highlands of Ethiopia," Environ. Syst. Res., vol. 7, no. 1, 2018, doi: 10.1186/s40068-018-0118-9. 